\title{
EFFECTS OF GENIPOSIDE ON THE REGULATION MECHANISMS OF PHOTOSYNTHETIC PHYSIOLOGY, ROOT OSMOSIS AND HORMONE LEVELS IN MAIZE UNDER SALINE- ALKALI STRESS
}

\author{
LIU, Z. Y. ${ }^{1 \#}-$ XU, W. H. ${ }^{2 \#}-$ GU, W. R. $.^{1 *}-$ LI, J. ${ }^{1}-$ LI, C. F. ${ }^{3}-$ WANG, M. Q. ${ }^{4}-$ ZHANG, L. G. ${ }^{4}-$ \\ PIAO, L. ${ }^{4}-$ ZHU, Q. R. ${ }^{5}-$ WEI, S. ${ }^{1}$ \\ ${ }^{1}$ College of Agronomy, Northeast Agricultural University, Changjiang Road 600, 150030 \\ Harbin, Heilongjiang, China
}

${ }^{2}$ CAS Key Laboratory of Forest Ecology and Management, Institute of Applied Ecology, Chinese Academy of Sciences, 110016 Shenyang, China

${ }^{3}$ Institute of Crop Science, Chinese Academy of Agricultural Sciences, No.12 Zhongguancun South Street, Haidian District, 100081 Beijing, China

${ }^{4}$ Maize Research Institute, Heilongjiang Academy of Agricultural Sciences, No.11 Scientific Research Street, 150086 Harbin, Heilongjiang, China

${ }^{5}$ Guangxi Shan Yun Biochemical Science and Technology Co., Ltd, Luzhai County Industrial Park, 545600 Liuzhou, Guangxi, China

${ }^{\#} L i u, Z$. H. and $X u, W$. H. are co-first authors.

*Corresponding author

e-mail: wanronggu@163.com

(Received $2^{\text {nd }}$ Sep 2020; accepted $19^{\text {th }}$ Jan 2021)

\begin{abstract}
The aim of the study was to monitor the effects of exogenous geniposide (GD) on maize (Zea mays L.) and explore the mechanisms through which it mitigates saline-alkali stress to provide a theoretical basis for revealing the growth physiology and chemical regulation processes in maize. The control (CK) received nutrient solution culture while the group under saline-alkali stress(SAS) received $150 \mathrm{mmol} \mathrm{L}^{-1}$ saline-alkali solution (molar concentration ratio $\left.\mathrm{NaCl}: \mathrm{Na}_{2} \mathrm{SO}_{4}: \mathrm{NaHCO}_{3}: \mathrm{Na}_{2} \mathrm{CO}_{3}=1: 9: 9: 1\right)$. 'Jilong2' (saline-alkali tolerant) and 'Xinxuan58' (saline-alkali sensitive) were chosen as experimental materials and were cultivated with hydroponic method. Maize received the saline-alkali solution 12 hours after GD treatment and saline-alkali solution was administered 3 times, every 12 hours. The GD and saline-alkali solution group constituted the $\mathrm{S}+\mathrm{G}$ treatment which promoted maize and a significant increase was observed in fresh and dry weights, plant height and photosynthetic enzymes in the leaf along with a significant decrease in the root to shoot ratio compared with saline-alkali treatment. The indoleacetic acid (IAA), zeatin-riboside (ZR), gibberellin (GA), superoxide radical $\left(\mathrm{O}_{2}^{-}\right)$generation rate, malonaldehy (MDA) and hydrogen peroxide $\left(\mathrm{H}_{2} \mathrm{O}_{2}\right)$ levels in roots were significantly lower than in the $\mathrm{S}+\mathrm{G}$ treatment under saline-alkali stress, while the level of abscisic acid (ABA) and the activity of antioxidative enzymes increased.
\end{abstract}

Keywords: maize seedlings, photosynthetic enzyme, osmotic substance, antioxidant enzyme, hormone

\section{Introduction}

Enrichment of soil soluble saline-alkali can change soil physical and chemical properties, even brings about land salinization. The salinization and alkalization in soil often occurs together in natural conditions. High concentrations of salts and alkali causes injury to plants not only with ionic, osmotic and oxidative stresses to plants, but also through high 
$\mathrm{pH}$ leading to a block in the transportation of substances required for nutrition (Mukhtar et al., 2019). Salinization is a severe trouble that threatens agricultural development worldwide, the area of saline-alkali soil is increasing year by year, most of which are not exploited and utilized (Zhao et al., 2020). The total area of saline-alkaline soils is $9.5 \times 10^{8}$ $\mathrm{ha}^{2}$ worldwide. Especially in China, saline-alkaline soils were widely distributed in several provinces of Northwest China, Northeast China, North China and Central China. Salinealkaline land with agricultural development potentially occupies over $10 \%$ of the total cultivated area of China. Songnen Plain is one of the most widely distributed area in salinealkali soils all over the world and it is located in the northeast China. The saline-alkali area is estimated at 3.73 million hectares and was still increasing at a speed of $1.4 \%$ per year (Litalien et al., 2020).

Maize is considered to be particularly sensitive to saline-alkali stress during seedling stage. Therefore, revealing the adaptive and protective mechanisms of maize to saline-alkali stress is of great theoretical significance and practical value. Assimilation of inorganic carbon by photosynthesis is the main source of $\mathrm{CO}_{2}$ organic matter in plant assimilation, plant growth and biomass accumulation (Huang et al., 2019). The primary pathway of photosynthetic carbon fixation in higher plants contains three kinds that is $\mathrm{C}_{3}$ pathway, $\mathrm{C}_{4}$ pathway and Crassulacean acid metabolism (CAM) pathway. $\mathrm{C}_{4}$ pathway is the physiological basis of $\mathrm{C}_{4}$ crops such as maize of high photosynthetic efficiency, biomass potential and crop yield formation under saline-alkali stress (Hughes et al., 2019).

The main physiological function of PEPCase in $\mathrm{C}_{4}$ plant photosynthesis is to use PEP as substrate to fix $\mathrm{CO}_{2}$ and produce oxaloacetate, and oxaloacetate(OAA) is catalysed to malic acid by MADP-ME. Malate is metabolized by NADP-MDH to produce $\mathrm{CO}_{2}$ and pyruvate, PEP use pyruvate as a substrate to be produced by PPDK catalysis and returned to the $\mathrm{C}_{4}$ cycle. Studies have shown that plants convert carbon dioxide via $\mathrm{C}_{4}$-pathway and Calvin cycle immobilization under the influence of the activity of related metabolic photosynthetic enzymes, such as phosphoenolpyruvate carboxylase (PEPCase), pyruvate dikinase (PPDK), NADP-malatease (NADP-ME), malate dehydrogenase (NADP-MDH) and ribone glycol diphosphate carboxylase (RuBPCase) (Lei et al., 2017). This indicated that saline-alkali stress slowed down the $\mathrm{CO}_{2}$ assimilation rate in crops, resulting in decreased enzyme activity, which further disrupted the balance of consumption and accumulation of metabolites in the $\mathrm{C}_{4}$ pathway and Calvin cycle, and reduces the content of assimilates transported to roots, which affect root growth (Zhao et al., 2019). The production of reactive oxygen species is affected by saline-alkali stress, which affect hormone metabolism and distribution, and destroys hormone balance. There are synergistic or antagonistic effects between endogenous hormones. Hormones can be used as an endogenous signal in response to abiotic stress. Plant hormones can be signals involved in physiological functions and metabolism. IAA play a major role in root growth of maize seedlings, GA induces cell elongation, ZR is an important form of CTK transport in xylem, and ABA is a growth inhibitor to slow seedling growth under saline-alkali stress. The production of reactive oxygen species (ROS) was led by salt-alkali stress, which in turn affects hormone metabolism and distribution, and destroys hormone balance (Li et al., 2017). The accumulation of soluble sugar and proline can effectively maintain the normal metabolism of plant roots because of reducing the osmotic potential of plant cells, eliminating free radicals and ROS, thus relieving oxidative stress (Amira et al., 2020). At present, some progress has been made in the application of physiological control measures of exogenous substances in agricultural production, such as amendments (Wang et al., 2016), trehalose (Rohman et al., 2019), abscisic acid (Lu et al., 2019), humic acid (Kaya et al., 2018) and 
salicylic acid (Taha et al., 2019), which can effectively alleviate the injury of crops under saline-alkali stress. GD is a class of cyclic ether terpenoids (Iridoids) that exhibit a wide variety of biological activities and are widely distributed in the plant kingdom. GD content in gardenia is about 5\%. As a natural extract, GD is non-toxic and has high biological activity, soluble in water, safe and convenient to use, mainly includes Gentiopicroside, Vanilloylcatalpol and geniposide. GD has wide-ranging beneficial applications in the avoidance of neuroprotection and anti-diabetes as well as GD has the effect of protecting the liver and the gallbladder (Wu et al., 2019). In agricultural production, GD also plays an important role in the growth of crops, and the compound product-enhancing agent prepared by GD can effectively increase the yield of cucumber, cowpea, wheat and cotton (Zhang et al., 1998a,b; Zhang et al., 1999a,b). It can also promote the growth and development of maize seedlings, improve the chlorophyll content and chlorophyll light energy conversion efficiency in the leaves of green vegetables, promote the accumulation of soluble sugar and soluble protein, and enhance the photosynthetic ability of plant leaves. GD could promote root growth, thus increasing plant biomass under saline-alkali stress.

At present, effects of GD on growth and development of maize seedlings under salinealkali stress have not been reported. Effects of exogenous GD on growth morphology, seedling biomass, leaf photosynthetic enzyme activity, root osmotic regulation, antioxidant system and endogenous hormones under saline-alkali stress of different saline-alkali tolerant maize seedlings were investigated.

In this study, the effects of exogenous GD on growth morphology, seedling biomass, leaf photozyme activity, root osmotic regulatory substance content, antioxidant system and endogenous hormones of saline-alkali resistant maize seedlings under saline-alkali stress were investigated with two varieties as test materials, and it provides theoretical and experimental basis for the application of exogenous GD in maize field stress tolerance production.

\section{Materials and methods}

\section{Study design and experimental procedures}

In the present study, we choose maize (Zea mays L.) Jilong2 and Xinxuan58 cultures to be transplanted into nutrient solution after seedling stage. The maize cultures were provided by Heilongjiang jiulong seed industry co., LTD and Shenyang xinxuan agricultural science and technology co., Ltd. The concentrations and treatment duration of the agents used in this study were determined after preliminary experiments. GD was provided by Guangxi Shan Yun Biochemistry Technology Co., Ltd, the treatment concentration was $5 \mathrm{mg} \mathrm{L}^{-1}$, and its molecular weight was 388.37 , and the purity was $>98 \%$. The saline-alkali solution was prepared, in which the major constituents were $\mathrm{NaCl}: \mathrm{Na}_{2} \mathrm{SO}_{4}: \mathrm{NaHCO}_{3}: \mathrm{Na}_{2} \mathrm{CO}_{3}$ with a molar ratio of 1:9:9:9:1. Light absorbance was measured by a UV-visible spectrophotometer (UV-5500, manufactured by Shanghai Metash Insruments Co., Ltd.).

A hydroponic experiment was performed under different treatment conditions in the maize cultivation physiology laboratory of the Agricultural College of Northeast Agricultural University in June 2019. Maize seeds were surface-sterilized by rinsing them for $2 \mathrm{~min}$ in a $10 \% \mathrm{NaClO}$ solution, then the seeds were rinsed with distilled water for several times, and soaked in distilled water for $8 \mathrm{~h}$. Germination tests were carried out in an incubator at $25 \pm 1^{\circ} \mathrm{C}$ with $75 \%$ humidity. The uniformly germinated seeds were selected after $48 \mathrm{~h}$ incubation and cultivated in a test pot $(60 \mathrm{~cm}$ in length, $30 \mathrm{~cm}$ in width, $12 \mathrm{~cm}$ in high) containing $150 \mathrm{~L} \mathrm{1/2}$ Hoagland nutrient solution ( $\mathrm{pH} 6.0 \pm 0.1)$ with 25 seedlings in 
each pot with nutrient solution supply (CK), saline-alkali solution supply (SAS), saline-alkali solution and GD supply (S+G) or GD solution supply (GD). The cultures were maintained in standard conditions of day room temperature $\left(28 \pm 1^{\circ} \mathrm{C}\right)$, night room temperature $\left(25 \pm 1^{\circ} \mathrm{C}\right)$ with $65 \%-75 \%$ humidity, on a 12-h light and 12-h dark cycle with a light intensity of 4000 lx. The nutrient solution was changed in every 3 days, and water was supplied with oxygen by air pump every day. When the plants had 3 true leaves, the seedlings were divided into four groups before further treatment. Fifty seedlings were used for each set of experiments. The seedlings were randomly assigned to one of the four groups: control group (CK), saline-alkali group (SAS), GD and saline-alkali group (S+G) or GD group (GD). The CK treatment received 1/2 Hoagland nutrient solution. The SAS treatment received $1 / 2$ Hoagland nutrient solution and $150 \mathrm{mmol} \mathrm{L}^{-1}$ saline-alkali solution. The $\mathrm{S}+\mathrm{G}$ treatment received $1 / 2$ Hoagland nutrient solution, $150 \mathrm{mmol} \mathrm{L}^{-1}$ saline-alkali solution and $5 \mathrm{mg} \mathrm{L}^{-1} \mathrm{GD}$. The GD treatment received 1/2 Hoagland nutrient solution and 5 $\mathrm{mg} \mathrm{L}^{-1} \mathrm{GD}$. To avoid the impact of saline-alkali stress on maize seedlings, saline-alkali solution was added to the maize 12 hours after GD treatment and saline-alkali solution was administered 3 times, every 12 hours. Saline-alkali solution reaching $150 \mathrm{mmol} \mathrm{L}^{-1}$ marked Day 0. Seedlings were sampled at 4th $d$ of germination for biochemical and physiological measurements. All experiments were repeated a minimum of 3 times.

\section{Agronomic characters of maize seedlings}

Three plants of each treatment were harvested on the 4th day. Plants were rinsed with distilled water and, after removing the excess water with filter paper the fresh and dry weight of the seedlings was measured by a balance. After the plant samples were heated for $30 \mathrm{~min}$ at $105^{\circ} \mathrm{C}$ to halt metabolism, and dried at $80^{\circ} \mathrm{C}$ to constant weight for assays of dry weight and the average value was taken as the final result, the fresh and dry weight has units of $g$ 3 plant $^{-1}$ (take the total weight of three seedlings as the unit). Height was measured from the base of the seedlings to its highest point and the average value was taken as the final result, the plant height has units of $\mathrm{cm}$. Root dry weight was divided by stem dry weight to calculate the root-shoot ratio $(\mathrm{R} / \mathrm{S})$.

\section{Measuring photosynthetic activity of maize leaves}

Photosynthesis was measured during the study at day 4. The third true leaves from three plants of maize seedlings were cut for measurements. The enzyme extraction and activity of PEPCase and RuBPCase was performed according to a modified method of Sayre (1979). The concentration of the standard substance and the OD value at $490 \mathrm{~nm}$ of each sample were determined sequentially on the enzyme-linked immunoassay spectrophotometer. RuBPCase determination: $0.1 \mathrm{ml}$ of the enzyme solution was mixed with $0.3 \mathrm{ml} 0.1 \mathrm{~mol} \mathrm{~L}^{-1}$ Tris- $\mathrm{HCl}$ (pH 8.0), $0.3 \mathrm{ml} 0.1 \mathrm{~mol} \mathrm{~L}^{-1} \mathrm{MgCl}_{2}, 0.3 \mathrm{ml} 50 \mathrm{mmol} \mathrm{L}^{-1}$ adenine nucleoside triphosphate (ATP), $0.3 \mathrm{ml} 50 \mathrm{mmol} \mathrm{L}^{-1}$ dithiothreitolol (DTT), $0.3 \mathrm{ml} 2.0 \mathrm{mmol} \mathrm{L}^{-1} \mathrm{NADH}, 0.3 \mathrm{ml} 1.0$ mmol L-1 EDTA-Na, $0.1 \mathrm{ml} 200 \mu \mathrm{mol} \mathrm{L}{ }^{-1} \mathrm{NaHCO}_{3}, 1.0 \mathrm{ml}$ distilled water and $0.1 \mathrm{ml} \mathrm{3-}$ phosphoglycerate kinase (PGK)/ 3-glyceraldehyde phosphate dehydrogenase (GAP-DH) (15 $\mathrm{u} / 15 \mathrm{u}$ ) buffer preheated in 30 constant temperature water bath for $10 \mathrm{~min}$. The absorbance $\mathrm{E}_{0}$ of the samples was measured at a wavelength of $340 \mathrm{~nm}$ with distilled water as a reference wavelength. Then $0.1 \mathrm{ml} 9 \mathrm{mmol} \mathrm{L}^{-1}$ 1,5-ribose diphosphate (RuBP) was added to initiate the reaction, the changes in light absorption was determined in $15 \mathrm{~s}$ intervals. PEPCase determination: the enzyme solution $1 \mathrm{ml}$ was mixed with $1 \mathrm{ml} 0.1 \mathrm{~mol} \mathrm{~L}^{-1} \mathrm{H}_{2} \mathrm{SO}_{4}(\mathrm{pH} 9.2$ ), $0.1 \mathrm{ml} 10 \mathrm{mmol} \mathrm{L} \mathrm{LgCl}_{2}, 0.1 \mathrm{ml} 10 \mathrm{mmol} \mathrm{L}^{-1} \mathrm{NaHCO}_{3}, 0.2 \mathrm{ml} 40 \mathrm{mmol} \mathrm{L}^{-1}$ phosphoenolpyruvate (PEP), $0.3 \mathrm{ml}^{1} \mathrm{mg} \mathrm{ml}^{-1} \mathrm{NADH}, 0.2 \mathrm{ml}$ malic dehydrogenase (MDH) 
then pre-heated by water bath at $28^{\circ} \mathrm{C}$ for $10 \mathrm{~min}$, the reaction was initiated with $0.2 \mathrm{ml}$ PEPC extract, and the decrease of sample absorbance was measured rapidly at $340 \mathrm{~nm}$. To determine the activity of NADP-MDH, NDAP-ME and PPDK a kit was used according to the operating procedures of the instructions. At least three replicates for each assay were performed. The average of test result was calculated and analyzed. Experiments were repeated thrice and three repeats were performed each time.

\section{Measuring endogenous hormone content of maize roots}

Endogenous hormone content was measured during the study at day 4 . The contents of IAA, ZR, GA and ABA in maize root were analyzed using an enzyme-linked immunosorbent assay. $0.5 \mathrm{~g}$ tissue samples (maize leaves) were ground in $2 \mathrm{ml}$ sample extract under ice bath to form homogenate, and samples were transferred into the test tube and extracted under $4^{\circ} \mathrm{C}$ for $4 \mathrm{~h}$, then centrifuged at $3500 \mathrm{r} / \mathrm{min}$ for $8 \mathrm{~min}$ at $4^{\circ} \mathrm{C}$, and the supernatants were collected into a $10 \mathrm{ml}$ centrifuge tube. $1 \mathrm{ml}$ of extract was added in the precipitate and laid still at $4^{\circ} \mathrm{C}$ for $1 \mathrm{~h}$, then centrifuge, the supernatant was taken merge with the previous supernatant and record the volume, the residue is discarded. Use a C-18 solid phase extraction column to purity the supernatant. After passing through the column, the sample was transferred into a 5 $\mathrm{ml}$ plastic centrifuge tube. The methanol in the extract was removed by vacuum, concentrated and dried or blown dry with nitrogen and the volume was fixed with the sample diluent. After extracting the hormone, the maximum concentration of the ABA is $500 \mathrm{ng} \mathrm{ml}^{-1}$, IAA and ZR is $100 \mathrm{ng} \mathrm{ml}^{-1}$, GA is $10 \mathrm{ng} \mathrm{ml}^{-1}$, and then diluted 2 times , 4 times , 8 times , 16 times ,32 times ,64 times until there are 8 concentrations (including $0 \mathrm{ng} / \mathrm{ml}$ ). The series of standard samples were added to the first two rows of a 96-well enzyme standard plate, add samples to be tested to the remaining holes, and add the same sample every two holes, $50 \mu \mathrm{l}$ per hole. A certain amount of anti-mixing was added to the $5 \mathrm{ml}$ sample diluent, then the enzyme label plate was put into the wet box to start the competition. The competitive conditions were $37^{\circ} \mathrm{C}$ and $0.5 \mathrm{~h}$. Washing boards: get rid of the reaction fluid on the board and pat it clean on paper. Get rid of it immediately after adding washing liquid to the board, repeat four times. Appropriate enzymatic II antibodies were added in $10 \mathrm{ml}$ sample diluents, each hole was $100 \mu \mathrm{l}$, then the enzyme labeling board was incubated in wet box at $37^{\circ} \mathrm{C}$ for $0.5 \mathrm{~h}$. Wash again. $10 \mathrm{mg}$ ophenylenediamine (OPD) was completely dissolved in $10 \mathrm{ml}$ substrate buffer and mixed with $4 \mu \mathrm{l} 30 \% \mathrm{H}_{2} \mathrm{O}$, each hole was $100 \mu \mathrm{l}$, and the enzyme label plate was placed into the wet box until appropriate color development, then $50 \mu 12 \mathrm{~mol} \mathrm{~L}^{-1}$ sulfuric acid was added to each hole to terminate the reaction. The concentration of the standard substance and the OD value at $490 \mathrm{~nm}$ of each sample were determined sequentially on the enzyme-linked immunoassay spectrophotometer. Experiments were repeated thrice and three repeats were performed each time.

\section{Osmotic content in maize roots measurement}

Osmotic content was measured during the study at day 4. The anthrone colorimetric method was used to determine the soluble sugar content in maize roots. The standard curve was established using sucrose. The $0.3 \mathrm{~g}$ root was cut into pieces and put into the scale test tube together with $5 \mathrm{ml}$ distilled water and sealed with plastic film. Samples were extracted in boiling water for $30 \mathrm{~min}$ the extraction was performed two times. The extract was filtered into $25 \mathrm{ml}$ volumetric flasks, the test tube was washed with distilled water, and the residues were transferred into volumetric flasks and diluted to $25 \mathrm{ml} .0 .5 \mathrm{ml}$ extract was transferred by $1.5 \mathrm{ml}$ of distilled water to a $20 \mathrm{ml}$ scale tube, $0.5 \mathrm{~mL}$ anthrone and ethyl acetate were 
added into the mixture. The samples were placed in a boiling water bath for $1 \mathrm{~min}$ then cooled to room temperature. The absorbance of the samples was measured at a wavelength of $630 \mathrm{~nm}$ with blank space as a reference wavelength. Soluble sugar content was calculated with the following formula:

$$
\text { Soluble sugar content }[\mathrm{mg} \mathrm{g}-1]=(2500 \times \mathrm{C}) / 0.3 \mathrm{~g} \text {, }
$$

where $\mathrm{C}$ is soluble sugar content of determination solution on standard curve. Soluble sugar content. Proline content in maize root was determined according to ninhydrin coloring method. Before sample measurement, standard curves were made with different concentrations of $2 \mathrm{ml}$ standard solutions of proline. $0.5 \mathrm{~g}$ of fresh leaves and $5 \mathrm{ml} 3 \%$ sulfosalicylic acid were added to the test tube and then transferred to boiling water for 10 min. After cooling, the extract was filtered. After that, $2 \mathrm{ml}$ filtrated extraction mixed with a $2 \mathrm{ml}$ ninhydrin reagent and $2 \mathrm{ml}$ glacial acetic acid. The mixture was heated in a boiling water bath for $30 \mathrm{~min} .4 \mathrm{ml}$ of toluene was added after cooling and shaken for $30 \mathrm{~s}$ and the supernatants were collected into a $10 \mathrm{ml}$ centrifuge tube. The supernatant was poured into a colorimetric cuvette and water was used as blank control. The absorbance values were read at $520 \mathrm{~nm}$. Proline content was calculated with the following formula:

$$
\text { Proline content }[\mu \mathrm{g} g-1]=2500 \times \mathrm{C} \text {, }
$$

where $\mathrm{C}$ is $2 \mathrm{ml}$ proline content of determination solution on standard curve.

\section{Determination of superoxide anion production rate and hydrogen peroxide content in maize root system and antioxidant enzyme system}

Photosynthesis was measured during the study at day 4. $\mathrm{O}_{2}^{-}$generation rate was measured using a hydroxylamine oxidization method. For determining $\mathrm{O}_{2}^{-}$generation rate, $5 \mathrm{~g}$ tissue samples (maize root-tip) were ground in $6 \mathrm{ml}$ of $65 \mathrm{mmol} \mathrm{L}^{-1}$ phosphate buffer solution (PBS) (pH 7.8) into a homogenate, after filtration through four layers of gauze, centrifuged at $5000 \mathrm{r} / \mathrm{min}$ for $10 \mathrm{~min}$ at $4^{\circ} \mathrm{C}$. Then, $1 \mathrm{ml}$ (about $0.5 \mathrm{mg}$ protein) supernatant was mixed with $0.9 \mathrm{ml}$ PBS and $0.1 \mathrm{ml} 10 \mathrm{mmol} \mathrm{L}^{-1}$ hydroxylamine chloride for reaction for $20 \mathrm{~min}$ at $25^{\circ} \mathrm{C}$. Supernatant $(0.5 \mathrm{~mL})$ was mixed with $0.5 \mathrm{ml} 7 \mathrm{mmol} \mathrm{L}^{-1} \mathrm{p}$ aminophenylsulfonic acid and $0.5 \mathrm{ml} 7 \mathrm{mmol} \mathrm{L}^{-1} \alpha$-naphthylamine, and incubated for 20 $\min$ at $25^{\circ} \mathrm{C}$. After the reaction, the same volume of n-butanol was added and shaken vigorously, and laid still for layer separation. The intensity of the chromogenic agent in the butanol layer was determined at $530 \mathrm{~nm}$ and sample solution was replaced with phosphate buffer. Both supernatants were combined and centrifuged for $5 \mathrm{~min}$ at $1500 \times \mathrm{g}$ and absorbance was measured at $530 \mathrm{~nm}$.

The $\mathrm{H}_{2} \mathrm{O}_{2}$ content was determined spectrophotometrically. First, $2 \mathrm{~g}$ of fresh sample was weighed, precooled at $4^{\circ} \mathrm{C}$, acetone with quartz sand was added at a ratio of $1: 1$, and the homogenate was ground. Then, it was centrifuged at $3000 \mathrm{rpm}$ for $10 \mathrm{~min}$ and the supernatant $\left(\mathrm{V}_{\mathrm{t}}\right)$ was taken. Finally, $5 \%$ titanium sulfate and ammonia water were added to the supernatant. When the solution became turbid, it was centrifuged again $5000 \mathrm{rpm}$ for 10 min. After discarding the clear supernatant, the precipitates were washed with acetone to remove plant pigments. Subsequently, $5 \mathrm{~mL}$ of concentrated sulfuric acid was added to the precipitates. When the precipitate dissolved, the sample volume was made up to $10 \mathrm{ml}$, the absorbance was measured at $415 \mathrm{~nm} . \mathrm{H}_{2} \mathrm{O}_{2}$ content was calculated with the following formula: 
$\mathrm{H}_{2} \mathrm{O}_{2}$ content $\left[\mathrm{nmol}^{-1} \mathrm{FW}\right]=\left(\mathrm{C} \times \mathrm{V}_{\mathrm{t}}\right) /(2 \mathrm{~g} \times 1 \mathrm{ml})$,

where $\mathrm{C}$ is the $\mathrm{H}_{2} \mathrm{O}_{2}$ content from the standard curve, $\mathrm{V}_{\mathrm{t}}$ : total volume of extracting enzyme solution.

The crude enzyme extraction for SOD (Superoxide dismutase), POD (Peroxidase), CAT (catalase), MDA was similar: $4 \mathrm{ml} 0.1 \mathrm{~mol} \mathrm{~L}^{-1} \mathrm{PBS}$ ( $\mathrm{pH}$ 7) was added to $2 \mathrm{~g}$ of each sample to crush in precooled mortar and pestle. The final volume was made up to $200 \mathrm{ml}$. The 1.5 $\mathrm{ml}$ homogenate was centrifuged at $10,000 \mathrm{rmp}$ at $4^{\circ} \mathrm{C}$ for $15 \mathrm{~min}$, and the crude enzyme extract was the supernatant. SOD activity was assayed by measuring the ability of inhibit photochemical reduction of NBT. $0.6 \mathrm{ml} 50 \mathrm{mmol} \mathrm{L}^{-1} \mathrm{PBS}, 0.12 \mathrm{ml} 130 \mathrm{mmol} \mathrm{L}^{-1} \mathrm{Met}$, $0.12 \mathrm{ml} 750 \mu \mathrm{mol} \mathrm{L}{ }^{-1} \mathrm{NBT}, 0.12 \mathrm{ml} 100 \mu \mathrm{mol} \mathrm{L}^{-1}$ EDTA-Na2, $0.12 \mathrm{ml} 20 \mu \mathrm{mol} \mathrm{L}^{-1}$ riboflavin, $0.02 \mathrm{~mL}$ of an enzyme solution (sections applied with PBS instead of enzyme solution were studied as the control) were mixed with $0.1 \mathrm{~mL}$ of distilled water in a $10 \mathrm{~mL}$ centrifuge tube and mixed gently. One control centrifuge tube was placed in the dark and the other samples reacted at $25^{\circ} \mathrm{C}$ under $4000 \mathrm{~lx}$ sunlight for $20 \mathrm{~min}$ (each tube was light consistent). One unit of SOD activity was defined as the quantity of enzyme required for $50 \%$ inhibition of NBT reduction at $560 \mathrm{~nm}$. POD activity was estimated using the guaiacol method. The reaction mixture contained $0.05 \mathrm{ml}$ of enzyme extract, $2.2 \mathrm{ml}$ PBS, $0.15 \mathrm{ml}$ of $1 \% \mathrm{H}_{2} \mathrm{O}_{2}$ and $0.6 \mathrm{~mL} 1 \%$ guaiacol solution and were warmed for $5 \mathrm{~min}$ at $37^{\circ} \mathrm{C}$ in a water bath. Reaction buffer without crude enzyme solution was used as the control. The change in absorbance at $470 \mathrm{~nm}$ was measured over a period of $3 \mathrm{~min}$ at $1 \mathrm{~min}$ intervals. We determined enzyme activity by measuring the change in absorbance per minute, and one unit (U) of enzyme activity was defined as the amount of the enzyme that changes the absorbance by 0.01 per minute. CAT activity was assayed using hydrogen peroxide as substrate. A $0.1 \mathrm{ml}$ enzyme sample and $2.865 \mathrm{~mL}$ PBS were added to a test tube, mixed, and placed in a boiling water bath for $10 \mathrm{~min}$. All the reaction mixture was incubated at $25^{\circ} \mathrm{C}$ for $5 \mathrm{~min}$ in the water bath. Then $0.035 \mathrm{ml} \mathrm{3 \%} \mathrm{H}_{2} \mathrm{O}_{2}$ was added and mixed well, the tube was quickly poured into the colorimetric cup and start to calculate the time. The colorimetric reaction was read at $450 \mathrm{~nm}$, each record lasted 3 min and was set at $1 \mathrm{~min}$ intervals, and enzyme volume of 0.01 absorbance per minute was regarded as one unit (U) of enzyme activity. The content of MDA was determined by thiobarbituric acid (TBA) reaction chronometry. Two milliliter of the enzyme solution was mixed with $2 \mathrm{ml}$ of $0.6 \%$ TBA, and the mixture was placed in a boiling water bath for $10 \mathrm{~min}$. The absorbance of the resulting supernatant was measured respectively at the wavelength of 532, 600, and $450 \mathrm{~nm}$ after cooling and centrifuge.

For SOD activity determination the absorbance values of the control tube and the measuring tube were measured by a spectrophotometer at $560 \mathrm{~nm}$ to be A0 and A, respectively. Percentage of inhibition was calculated as $\mathrm{P}[\%]=(\mathrm{A} 0-\mathrm{A}) / \mathrm{A} 0 \times 100$, and SOD activity as $\left[\mathrm{U} \mathrm{g}^{-1}\right]=114 \times \mathrm{P} /(1-\mathrm{P})$. For POD activity determination the absorbance value $\mathrm{A} 1$ at $1 \mathrm{~min}$ and the absorbance value $\mathrm{A} 2$ at $2 \mathrm{~min}$ at $470 \mathrm{~nm}$ were measured with a spectrophotometer. POD activity was calculated as $\left[\mathrm{U} \mathrm{g}^{-1}\right]=20,000 \Delta \mathrm{A}$, where $\Delta \mathrm{A}=\mathrm{A} 2-$ A1. CAT activity was calculated as $\left[\mathrm{U} \mathrm{g}^{-1}\right]=\Delta 240 \times \mathrm{V} / \mathrm{Va} / \mathrm{W}$. For MDA content determination the absorbance value $D_{600}$ at $600 \mathrm{~nm}$, value $D_{532}$ at $532 \mathrm{~nm}$ and value $D_{450}$ at $450 \mathrm{~nm}$ were measured with a spectrophotometer. MDA content was calculated as $\left(\mathrm{nmol} \mathrm{g}^{-1}\right.$ $F W)=\left(6.45 \times\left(D_{532}-D_{600}\right)-0.56 D_{450}\right) \times 0.015 / W$. Experiments were repeated thrice and three repeats were performed each time. 


\section{Data calculation and analysis}

The experimental data were statistically analyzed by Excel2010 software, variance analysis by SPSS17.0 software, and difference significance analysis by LSD method (Wu et al., 2014).

\section{Results}

\section{Effect of GD on maize growth phenotype under saline-alkali stress}

As shown in Table 1, a significant growth inhibition in maize seedlings has been caused by saline-alkali stress. Compared with the seedlings under the CK treatment, the seedlings under the SAS treatment had short plants and significantly decreased dry and fresh weight and root-shoot ratio increased. And compared with the seedlings under the SAS treatment, the seedlings under the $S+G$ treatment had long plants and significantly increased dry and fresh weight and root-shoot ratio decreased. This shows that exogenous GD had a better alleviating effect on dry-fresh weight and height of maize seedlings. Especially the GD treatment can have significant promoting effect on the shoot and the change of Xinxuan58 greater than that of Jilong2. It was observed that GD treatment greatly promoted dry-fresh weight, plants height and the growth of both maize cultivars compared with the CK. Seedling growth of Jilong2 and Xinxuan58 was significantly inhibited by saline-alkali stress (Fig. 1). Compared with the seedlings under the CK treatment, the seedlings under the SAS treatment had smaller leaves and roots, significantly decreased height and seedlings under the SAS treatment were wilting and some mature leaves showed chlorosis, the fibrous roots reduced, and seedlings growth was relatively inhibited. In both maize cultivars leaves of ecotype yellowed, and the area of yellowing in Jilong2 was larger than that in the Xinxuan58. The S+G treatment delayed leaf wilting in maize seedlings subjected to saline-alkali and fibrous roots increased. GD can effectively promote seedling growth, increase leaf width, promote root whitening, and increase fibrous roots.

Table 1. Effects of geniposide on the dry and fresh weight, plant height and root-shoot ratio of maize under saline-alkali stress on the fourth days

\begin{tabular}{|c|c|c|c|c|c|c|c|}
\hline \multirow{2}{*}{ Variety } & \multirow{2}{*}{ Treatment } & \multicolumn{2}{|c|}{$\begin{array}{c}\text { Fresh weight } \\
\text { (g 3-1 plant) }\end{array}$} & \multicolumn{2}{|c|}{$\begin{array}{l}\text { Dry weight } \\
\text { (g 3-1 plant) }\end{array}$} & \multirow{2}{*}{$\begin{array}{l}\text { Plant height } \\
(\mathrm{cm})\end{array}$} & \multirow{2}{*}{$\begin{array}{c}\text { Root-shoot } \\
\text { ratio }\end{array}$} \\
\hline & & $\begin{array}{l}\text { above } \\
\text { ground }\end{array}$ & lo & $\begin{array}{l}\text { above } \\
\text { ground }\end{array}$ & underground & & \\
\hline \multirow[t]{4}{*}{ Jilong2 } & $\mathrm{C}$ & $4.81 \pm 0.37^{\mathrm{b}}$ & $2.59 \pm 0.13^{b}$ & $0.31 \pm 0.074^{\mathrm{ab}}$ & $0.22 \pm 0.039^{\mathrm{b}}$ & $52.40 \pm$ & $0.54 \pm 0.04^{\mathrm{b}}$ \\
\hline & SAS & $1.63 \pm 0.18^{\mathrm{d}}$ & $1.95 \pm 0.06^{\mathrm{c}}$ & $0.20 \pm 0.059^{b}$ & $0.21 \pm 0.054^{\mathrm{b}}$ & $41.90 \pm 1.93^{\mathrm{d}}$ & $1.21 \pm 0.17^{\mathrm{a}}$ \\
\hline & $\mathrm{S}+\mathrm{G}$ & $2.44 \pm 0.15^{\mathrm{c}}$ & $2.55 \pm 0.13^{\mathrm{b}}$ & $0.34 \pm 0.058^{\mathrm{a}}$ & $0.37 \pm 0.032^{\mathrm{b}}$ & $48.40 \pm 1.40^{\mathrm{c}}$ & $1.04 \pm 0.02^{\mathrm{b}}$ \\
\hline & GD & $5.89 \pm 0.19^{\mathrm{a}}$ & $2.95 \pm 0.12^{\mathrm{a}}$ & $0.37 \pm 0.036^{\mathrm{a}}$ & $0.22 \pm 0.042^{\mathrm{a}}$ & $71.60 \pm 1.70^{\mathrm{a}}$ & $0.50 \pm 0.04^{\mathrm{b}}$ \\
\hline \multirow[t]{4}{*}{$\begin{array}{c}\text { Xinxuan } \\
58\end{array}$} & $\mathrm{CK}$ & $2.70 \pm 0.17^{\mathrm{b}}$ & $1.89 \pm 0.12^{b}$ & $0.18 \pm 0.060^{c}$ & $0.41 \pm 0.061^{\mathrm{a}}$ & $51.80 \pm 1.69^{\mathrm{a}}$ & $0.70 \pm 0.08^{\mathrm{b}}$ \\
\hline & SAS & $0.66 \pm 0.13^{\mathrm{c}}$ & $1.50 \pm 0.13^{\mathrm{b}}$ & $0.11 \pm 0.038^{c}$ & $0.31 \pm 0.042^{\mathrm{a}}$ & $43.50 \pm 1.94^{\mathrm{b}}$ & $2.19 \pm 0.48^{\mathrm{a}}$ \\
\hline & $\mathrm{S}+\mathrm{D}$ & $2.59 \pm 0.25^{\mathrm{b}}$ & $2.34 \pm 0.31^{\mathrm{a}}$ & $0.28 \pm 0.066^{\mathrm{b}}$ & $0.20 \pm 0.044^{\mathrm{b}}$ & $54.50 \pm 2.12^{\mathrm{a}}$ & $0.92 \pm 0.20^{\mathrm{b}}$ \\
\hline & GD & $4.96 \pm 0.12^{\mathrm{a}}$ & $2.64 \pm 0.21^{\mathrm{a}}$ & $0.39 \pm 0.020^{\mathrm{a}}$ & $0.21 \pm 0.056^{\mathrm{b}}$ & $54.40 \pm 1.91^{\mathrm{a}}$ & $0.53 \pm 0.04^{\mathrm{b}}$ \\
\hline
\end{tabular}

Different letters within the same variety and column indicate significant difference at 0.05 level. The same as below 

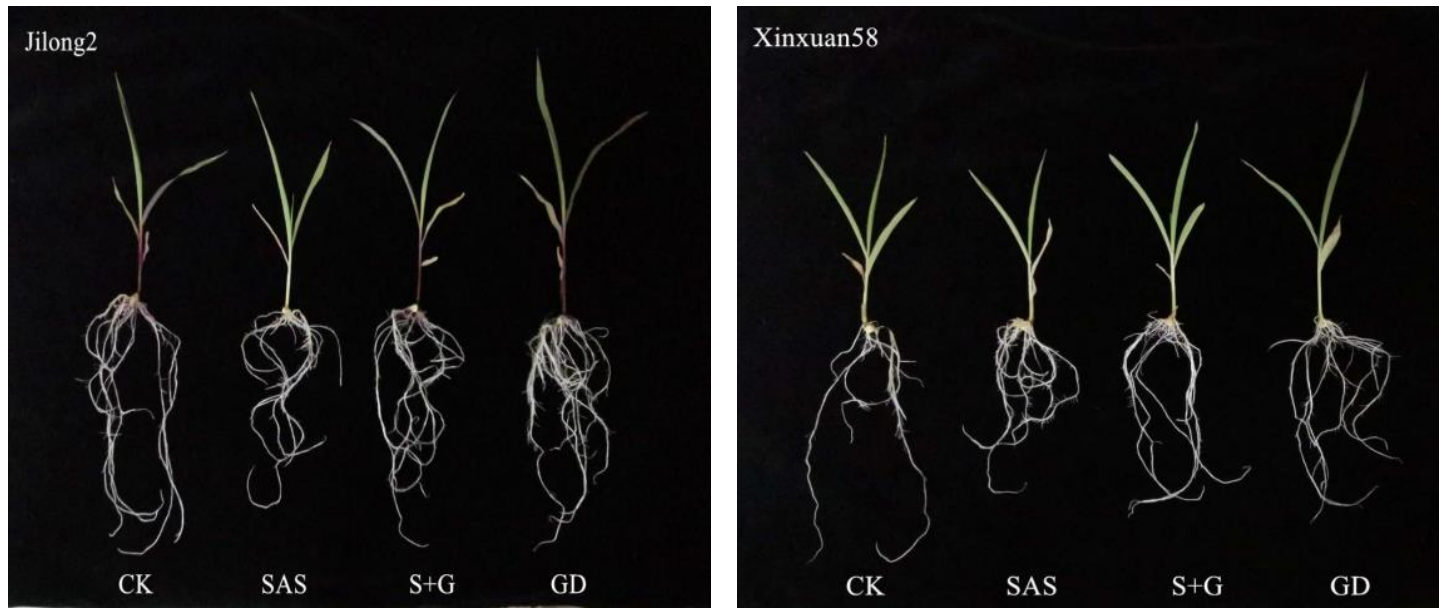

Figure 1. Effect of GD on growth morphology of maize under saline-alkali stress on the fourth day

\section{Effect of GD on photosynthetic enzyme activity of maize leaves under saline-alkali stress}

The main physiological function of PEPCase in $\mathrm{C}_{4}$ plant photosynthesis is to use PEP as a substrate to fix $\mathrm{CO}_{2}$ and produce oxaloacetate, and oxaloacetate(OAA) is catalysed to malic acid by MADP-ME. Malate is metabolized by NADP-MDH to produce $\mathrm{CO}_{2}$ and pyruvate, PEP use pyruvate as a substrate to be produced by PPDK catalysis and returned to the $\mathrm{C}_{4}$ cycle. An important carbon fixation in photosynthesis is the Calvin cycle. $\mathrm{CO}_{2}$ reacts with RuBP under RuBPCase catalysis in the Calvin cycle. Thus, photosynthetic enzyme reflects the photosynthetic activity of maize seedlings under saline-alkali stress (Fig. 2). Compared with the seedlings under the CK treatment, in the seedlings under the SAS treatment the activity of PEPCase, RuBPCase, NADP-ME, NADP-MDH and PPDK significantly decreased, the change of Xinxuan58 was greater than that of Jilong2. Compared with SAS treatment, there was no significant change in NADP-ME activity in Jilong2 under S+G treatment, while NADP-ME activity in Xinxuan58 increased. Compared with SAS treatment, in the seedlings under the $\mathrm{S}+\mathrm{G}$ treatment the activity of NADP-MDH, PPDK and RuBPCase significantly increased. This suggests that saline-alkali stress inhibits the photosynthetic pathway and GD treatment resulted in increased $\mathrm{C}_{4}$ photosynthesis activity.

\section{Effect of GD on endogenous hormone content and its ratio in maize roots under saline-alkali stress}

The plant adaptations to saline-alkali stress is reflected in changes of endogenous hormones and their ratios in maize under saline-alkali stress. Compared with CK, SAS treatment significantly inhibited the content of IAA in Jilong2, the relative content of endogenous IAA in Xinxuan58 was significantly increased and reached a notably high level (Table 2). The IAA concentration in Jilong2 and Xinxuan58 significantly increased under $\mathrm{S}+\mathrm{G}$ treatment compared to the SAS treatments, respectively. Compared with CK, SAS treatment significantly inhibited the content of GA and ZR, the change of GA in Xinxuan58 was greater than that in Jilong2. After $\mathrm{S}+\mathrm{G}$ treatment, the content of GA and ZR in roots of Jilong2 and Xinxuan58 was significantly greater than that in the SAS treatment. Compared with CK, SAS treatment significantly 
increased the content of ABA in Jilong2, and in Xinxuan58, ABA content decreased. The ABA content in $S+G$ treatment decreased relative to SAS treatment. Saline-alkali stress reduced IAA, GA and ZR contents in root of maize and inhibited plant growth. Under saline-alkali stress, increased levels of ABA may help to improve saline-alkali tolerance of plants. The accumulation of $\mathrm{ABA}$ content is conducive to plants to adaptation to stresses, and GD treatment can effectively alleviate the harm of salinealkali stress and promote hormone balance recovery.
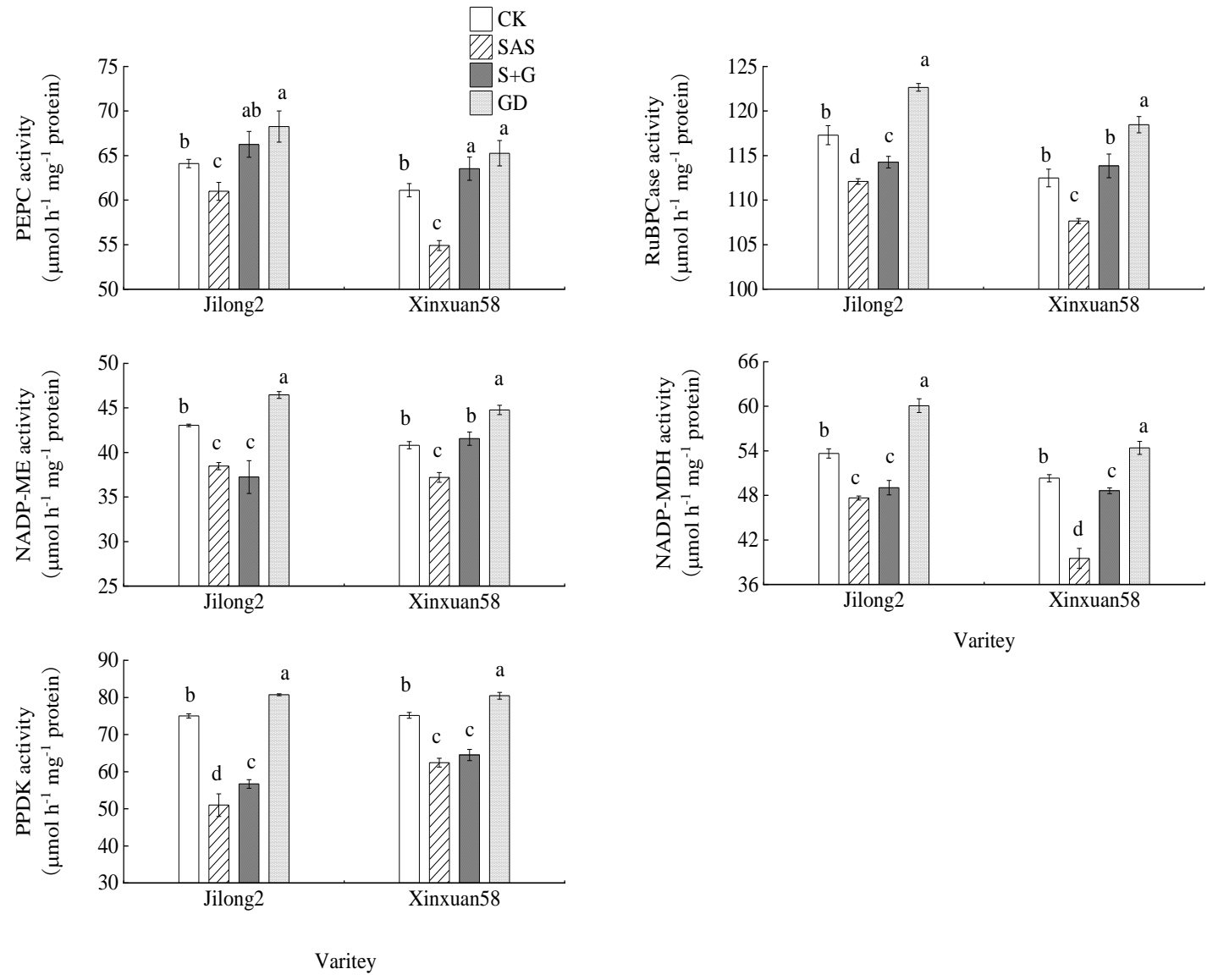

Figure 2. Effect of GD on photosynthetic enzyme activity in leaves of maize under saline-alkali stress on the fourth day. Different letters within the same variety and column indicate significant difference at 0.05 level

Hormone interaction in plants shows synergism or antagonism, the ratio of IAA/ABA, ZR/ABA and GA/ABA indicate different hormone impact on each other. The IAA/ABA and GA/ABA ratio in Jilong2 in SAS treatments decreased relative to $\mathrm{CK}$, that in Xinxuan58 increased. And ZR/ABA ratio has no significant change. Compared with SAS, S+G treatment the ratio of IAA/ABA, ZR/ABA and GA/ABA significantly increased in Jilong2 and Xinxuan58. The ratio of IAA/ABA, ZR/ABA and GA/ABA under SAS treatment was greater, indicating that growth-promoting hormone inhibits $\mathrm{ABA}$ action. Plants regulate energy distribution through hormones to support growth and development under stress. GD can change the hormone content under saline-alkali stress and keep the relative balance of hormone content in plants. 
Table 2. Effect of GD on endogenous hormones and hormones ratio in roots of maize under saline-alkali stress on the fourth day.

\begin{tabular}{|c|c|c|c|c|c|c|c|c|}
\hline Variety & Treatment & $\underset{\left(\text { ng g }^{-1}\right)}{\text { IAA }}$ & $\underset{\left(\text { ng g }^{-1}\right)}{\text { GA }}$ & $\underset{\left(\operatorname{ng~g}^{-1}\right)}{\mathbf{Z R}}$ & $\underset{\left(\mathbf{n g ~ g}^{-1}\right)}{\mathbf{A B A}}$ & IAA/ABA & GA/ABA & ZR/ABA \\
\hline \multirow{4}{*}{ Jilong2 } & $\mathrm{CK}$ & $\begin{array}{c}253.15^{ \pm} \\
10.23^{\mathrm{b}}\end{array}$ & $\begin{array}{c}376.47 \pm \\
2.65^{\mathrm{b}}\end{array}$ & $\begin{array}{c}125.44 \pm \\
2.46^{\mathrm{b}}\end{array}$ & $\begin{array}{c}146.21 \pm \\
3.97^{\mathrm{b}}\end{array}$ & $\begin{array}{l}1.73 \pm \\
0.04^{\mathrm{c}}\end{array}$ & $\begin{array}{l}0.89 \pm \\
0.02^{\mathrm{c}}\end{array}$ & $\begin{array}{l}2.58 \pm \\
0.09^{\mathrm{c}}\end{array}$ \\
\hline & SAS & $\begin{array}{c}196.98 \pm \\
3.96^{c}\end{array}$ & $\begin{array}{c}364.16 \pm \\
4.96^{\mathrm{c}}\end{array}$ & $\begin{array}{c}116.26 \pm \\
5.30^{\mathrm{b}}\end{array}$ & $\begin{array}{c}155.48 \pm \\
1.78^{\mathrm{a}}\end{array}$ & $\begin{array}{l}1.27 \pm \\
0.03^{\mathrm{d}}\end{array}$ & $\begin{array}{l}0.75 \pm \\
0.04^{\mathrm{d}}\end{array}$ & $\begin{array}{l}2.34 \pm \\
0.03^{\mathrm{c}}\end{array}$ \\
\hline & $\mathrm{S}+\mathrm{G}$ & $\begin{array}{c}249.37 \pm \\
3.40^{\mathrm{b}}\end{array}$ & $\begin{array}{c}395.31 \pm \\
10.33^{\mathrm{a}}\end{array}$ & $\begin{array}{c}148.29 \pm \\
11.20^{\mathrm{a}}\end{array}$ & $\begin{array}{c}106.43 \pm \\
1.68^{\mathrm{d}}\end{array}$ & $\begin{array}{c}2.34 \pm \\
0.13^{\mathrm{a}}\end{array}$ & $\begin{array}{l}1.39 \pm \\
0.11^{\mathrm{a}}\end{array}$ & $\begin{array}{l}3.71 \pm \\
0.08^{\mathrm{a}}\end{array}$ \\
\hline & GD & $\begin{array}{c}274.07 \pm \\
16.89^{\mathrm{a}}\end{array}$ & $\begin{array}{c}372.58 \pm \\
2.11^{\text {bc }}\end{array}$ & $\begin{array}{c}146.69 \pm \\
4.03^{\mathrm{a}}\end{array}$ & $\begin{array}{c}128.70 \pm \\
2.08^{\mathrm{c}}\end{array}$ & $\begin{array}{l}2.13 \pm \\
0.06^{\mathrm{b}}\end{array}$ & $\begin{array}{l}1.14 \pm \\
0.04^{\mathrm{b}}\end{array}$ & $\begin{array}{l}2.90 \pm \\
0.06^{\mathrm{b}}\end{array}$ \\
\hline \multirow{4}{*}{ Xinxuan58 } & $\mathrm{CK}$ & $\begin{array}{c}189.37 \pm \\
4.84^{\mathrm{c}}\end{array}$ & $\begin{array}{c}409.56 \pm \\
5.62^{\mathrm{b}}\end{array}$ & $\begin{array}{c}160.86 \pm \\
3.79^{\mathrm{b}}\end{array}$ & $\begin{array}{c}161.24 \pm \\
5.60^{\mathrm{a}}\end{array}$ & $\begin{array}{l}1.17 \pm \\
0.03^{\mathrm{d}}\end{array}$ & $\begin{array}{l}1.00 \pm \\
0.04^{\mathrm{c}}\end{array}$ & $\begin{array}{l}2.54 \pm \\
0.05^{\mathrm{c}}\end{array}$ \\
\hline & SAS & $\begin{array}{c}244.33 \pm \\
3.32^{\mathrm{b}}\end{array}$ & $\begin{array}{c}385.94 \pm \\
10.25^{\mathrm{c}}\end{array}$ & $\begin{array}{c}142.38 \pm \\
6.25^{\mathrm{c}}\end{array}$ & $\begin{array}{c}144.48 \pm \\
15.37^{\mathrm{b}}\end{array}$ & $\begin{array}{l}1.70 \pm \\
0.15^{\mathrm{c}}\end{array}$ & $\begin{array}{l}0.99 \pm \\
0.11^{\mathrm{c}}\end{array}$ & $\begin{array}{l}2.69 \pm \\
0.21^{\mathrm{c}}\end{array}$ \\
\hline & $\mathrm{S}+\mathrm{G}$ & $\begin{array}{c}269.25 \pm \\
10.44^{\mathrm{a}}\end{array}$ & $\begin{array}{c}407.80 \pm \\
9.61^{\mathrm{b}}\end{array}$ & $\begin{array}{c}159.03 \pm \\
4.01^{\mathrm{b}}\end{array}$ & $\begin{array}{c}123.77 \pm \\
1.21^{\mathrm{d}}\end{array}$ & $\begin{array}{l}2.18 \pm \\
0.01^{\mathrm{b}}\end{array}$ & $\begin{array}{l}1.29 \pm \\
0.04^{\mathrm{b}}\end{array}$ & $\begin{array}{l}3.30 \pm \\
0.09^{\mathrm{b}}\end{array}$ \\
\hline & GD & $\begin{array}{c}250.81 \pm \\
10.53^{\mathrm{b}}\end{array}$ & $\begin{array}{c}453.18 \pm \\
1.63^{\mathrm{a}}\end{array}$ & $\begin{array}{c}202.28 \pm \\
2.30^{\mathrm{a}}\end{array}$ & $\begin{array}{c}101.76 \pm \\
2.83^{\mathrm{c}}\end{array}$ & $\begin{array}{l}2.47 \pm \\
0.17^{\mathrm{a}}\end{array}$ & $\begin{array}{l}1.99 \pm \\
0.03^{\mathrm{a}}\end{array}$ & $\begin{array}{l}4.46 \pm \\
0.13^{\mathrm{a}}\end{array}$ \\
\hline
\end{tabular}

Different letters within the same variety and column indicate significant difference at 0.05 level. The same as below

\section{Effects of GD on antioxidant system and osmotic regulation of maize roots under saline-alkali stress}

In order to maintain the normal physiological function of the cells, the water potential of the cells was reduced by the accumulation of proline and soluble sugar under saline-alkali stress. The proline content in SAS treatment increased relative to $\mathrm{CK}$, the change of GA in Xinxuan58 was greater than that in Jilong2 (Fig. 3). And S+G treatment could further increase proline content. Compared with SAS treatment, soluble sugar content in two maize cultivars under $S+G$ treatment significantly increased. This indicates that the accumulation of proline and soluble sugar content can effectively alleviate the saline-alkali stress on the root of Jilong2, relatively, Xinxuan58 saline-alkali tolerance was weaker. GD treatment is beneficial to the accumulation of proline and soluble sugar content to maintain the normal function of root system under saline-alkali stress. The $\mathrm{H}_{2} \mathrm{O}_{2}$ contents and $\mathrm{O}_{2}{ }^{-}$generation rate in the root of Jilong2 and Xinxuan58 under SAS treatment increased compared with that of CK. The S+GD treatments had lower $\mathrm{H}_{2} \mathrm{O}_{2}$ contents and $\mathrm{O}_{2}^{-}$generation rate than the CK. SOD, POD and CAT activity and MDA content under SAS treatment higher than that of CK. Under SAS treatment, the POD and CAT activity of maize roots were consistent with the trend of SOD activity. And $\mathrm{S}+\mathrm{G}$ treatment significantly increased SOD, POD and CAT activity and MDA content compared with SAS treatment. GD can significantly alleviate the damage caused by saline-alkali stress on two maize cultivars, the change of antioxidant capacity Jilong2 was greater than that of Xinxuan58. 


$$
-1582-
$$
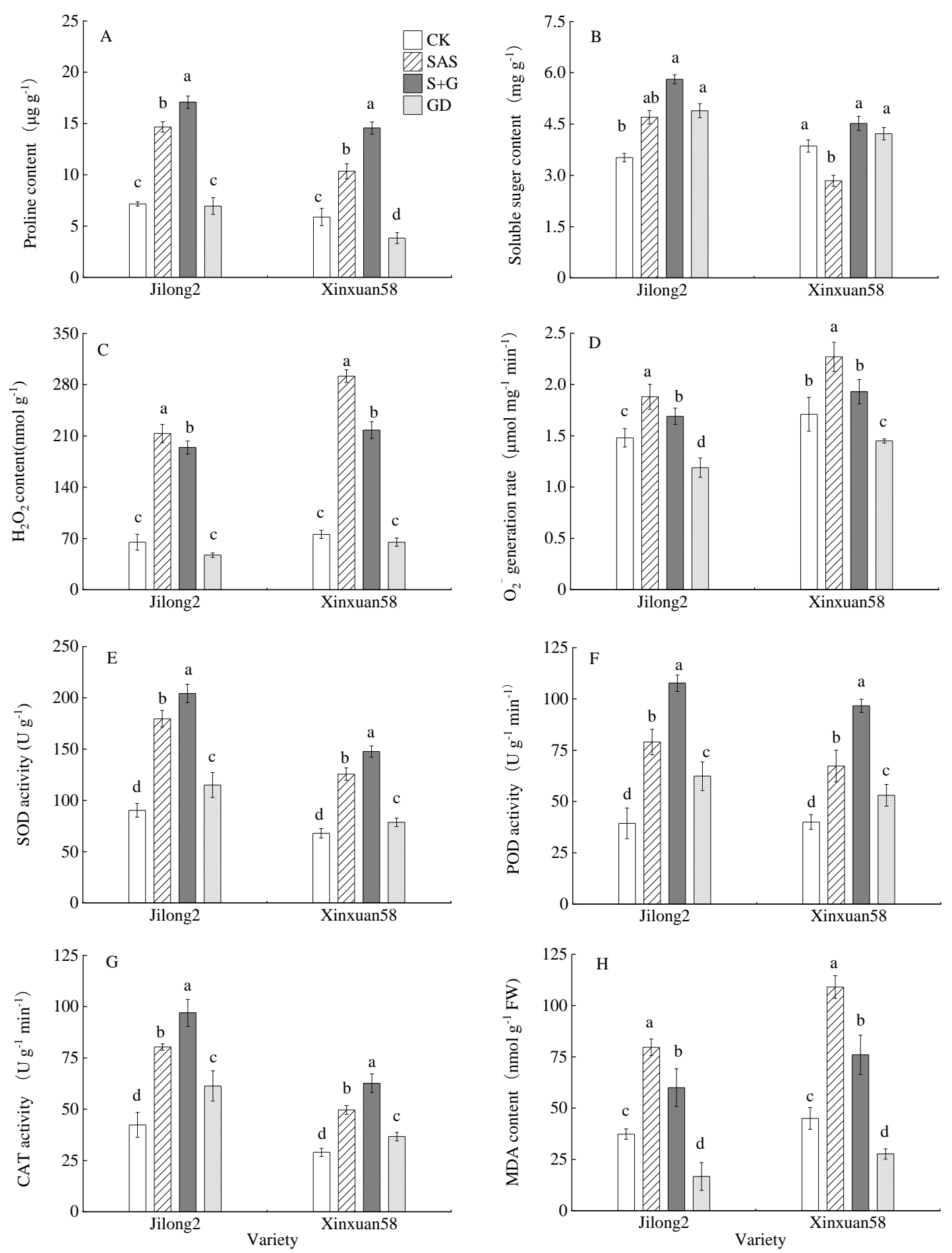

Figure 3. Effect of GD on permeating substances, antioxidase activity and MDA content in roots of maize under saline-alkali stress on the fourth day. A: Proline content; B: Soluble sugar content; $\mathrm{C}: \mathrm{H}_{2} \mathrm{O}_{2}$ content; D: $\mathrm{O}_{2}^{-}$generation rate; E: SOD activity; F: POD activity; G: CAT activity; H: MDA content. Different letters within the same variety and column indicate significant difference at 0.05 level 


\section{Discussion}

The accumulation of biomass is the mitigation and adaptation of plants to saline-alkali stress, and the difference of accumulation reflects the resistance of different plants (Razieh et al., 2019). Maize seedling dry-fresh weight and plant height decreased during saline-alkali stress, root-shoot ratio increased. This indicates that the growth of maize seedlings was inhibited under saline-alkali stress, the photosynthate produced was preferentially transferred to the root to maintain absorption of water and nutrients. Normal physiological function of root system is the basis of seedling growth. GD treatment markedly improved seedling growth under saline-alkali stress conditions, increased dry-fresh weight and plant height and decreased root-shoot ratio. Photosynthates in the growing period were normally allocated to each organs to increase the saline-alkali resistance of maize seedlings. Simple GD can promote root growth, increase plant dry-fresh weight and plant height, that can be used as growth promoters. Former study has shown that GD and its compound can promote dry-fresh weight of cucumber and cowpea (Zhang et al., 1998a). $25 \mathrm{mg} \mathrm{L}^{-1}$ GD could increase dry-fresh weight of radish, and improve the root-shoot ratio (Qian et al., 2016). It is proved that GD was propitious to increase plant biomass accumulation, and promote roots growth by promoting the transport of photosynthetic products to roots. Our conclusions are in line with these studies.

Photosynthesis is the physiological metabolism that provides energy for plants, photosynthetic efficiency is closely linked with biomass accumulation in plants. And photosynthetic efficiency is the foundation of plant growth. Photosynthetic enzyme activity can reflect the effect of saline-alkali stress on carbon assimilation pathway in maize plants. PEPCase play important roles in the regulation of responses to abiotic stresses and organic acid metabolism (Ueno et al., 2020). NADP - ME not only can catalyse reversible reactions of oxidative decarboxylation of malate, but also regulate pyruvate sources in plants through synergism between PEPCase and NADP-MDH (Borba et al., 2018). PEPCase has the function of maintaining the stability of cytoplasmic $\mathrm{pH}$ and osmotic potential. Research shows that NADP - ME activity of plants is increased by saline-alkali stress, and improve stress tolerance (Zhao et al., 2019). The present study shows that PEPC, PPDK, NADP-ME, NADP-MDH and RuBPCase activities were significantly decreased under saline-alkali stress compared to CK. Carbon assimilation rate in $\mathrm{C}_{4}$ photosynthesis was inhibited by saline-alkali stress, carbon assimilation rate reduced and assimilates translocation decreased (Kandoi et al., 2018; Dong et al., 2019). GD treatment significantly increased photosynthesis activity in maize leaves under saline-alkali stress, and GD could enhance the activity of photosynthesis to alleviate the inhibition of photosynthetic metabolism of maize seedlings under saline-alkali stress.

Plant endogenous hormone refers to the trace organic matter in plants, which can regulate plant physiological metabolism and directly or indirectly regulate plant growth. The level and distribution of endogenous hormones in plants follow the changes of external environment, so plants adapt to stress by regulating hormones. Regulation of hormone levels under abiotic stress can mediate physiological metabolic responses in plants and improve plant adaptability to adversity (Joshua et al., 2019). Studies have shown that saline-alkali stress may increase the level of reactive oxygen species (ROS), and ROS was capable of inhibiting the hormone synthesis, which leads to decreased hormone content (Jan et al., 2019). ABA is an endogenous signal to regulate stomatal closure to avoid water loss during saline-alkali stress treatment (Zhang et al., 2019b). 
The IAA, ZR and GA contents in SAS treatment decreased relative to CK, and the ABA content was higher in Jilong2 and lower in Xinxuan58. There was different saline-alkali tolerance among cultivars. Because the energy distribution of physiological metabolism in plants to osmotic regulation and antioxidant regulation is suppressed by ABA (Li et al., 2017, 2020), Jilong 2 can alleviate their own osmotic stress and antioxidant stress injury through induced ABA synthesis, and then improve maize resistance under stress. IAA/ABA, ZR/ABA and GA/ABA ratios directly reflect the relationship of endogenous hormones, and changes of endogenous hormone levels under saline-alkali stress affect the balance between hormones (Amany et al., 2019). According to the change of IAA/ABA, ZR/ABA and GA/ABA ratios under $\mathrm{CK}$ treatment and SAS treatment is explained ABA in Jilong2 is more sensitive to saline stress than IAA and GA, and ZR and ABA sensitivities are similar. Root system of Jilong2 by secreting ABA slows root growth and adaptation to saline-alkali stress. The response sensitivity of Xinxuan 58 to IAA was higher than that of Jilong 2, and ABA content decreased, so the tolerance was poor (Xie et al., 2019). This suggests that GD treatment effectively regulates endogenous hormone balance and promotes IAA, ZR and GA content. IAA, ZR and GA as $\mathrm{ABA}$ antagonists increased, which inhibited the production of $\mathrm{ABA}$, and alleviated the inhibition of root growth, improved the saline-alkali tolerance of maize roots.

The saline-alkali stress significantly decreased water potential and osmotic pressure, but increased cell expansion pressure in seedlings, which resulted in osmotic stress. Osmotic stress caused direct damage to maize plants and affected various physiological activities in plants (Amany et al., 2019). Studies have shown that accumulation of proline and soluble sugar content can reduce the cell permeability potential in maize roots and play an important role in maintaining water absorption in plant roots under saline-alkali stress. This study showed that the content of proline and soluble sugar was significantly higher than that of control in Jilong2 roots and lower than that in Xinxuan 58 root under saline-alkali stress, saline-alkali tolerant varieties can maintain the osmotic balance of plant cells by accumulating osmotic substances. GD can effectively promote the content of osmotic substances in maize roots under saline-alkali stress and improve the capacity of osmotic adjustment, which plays an important role in maintaining the water balance in roots of maize. Former study shows that $100 \mathrm{mg} \mathrm{L}^{-1}$ GD significantly increased soluble sugar content in willow leaves, which was consistent with the conclusion of this study (Zhang et al., 2018, 2019a). Plant cells accumulate a large amount of reactive oxygen species under saline-alkali stress, which leads to membrane lipid peroxidation and destruction of cell membrane structure and function, which leads to dysregulation of intracellular metabolism. Membrane lipid peroxidation under saline-alkali stress is closely related to active oxygen accumulation, indicating a disruption in the structure and function of the cell membrane, that leads to disturbance of lipid metabolism (Ahmad et al., 2019). SOD, PDD and CAT are a system of antioxidant enzymes that scavenge ROS in plants, the change of enzyme activity showed the plant resistance (Li et al., 2020).

The main function of SOD is to clear $\mathrm{O}_{2}^{-}$generate to form $\mathrm{H}_{2} \mathrm{O}_{2}$, and then $\mathrm{H}_{2} \mathrm{O}_{2}$ was decomposed into $\mathrm{O}_{2}$ and $\mathrm{H}_{2} \mathrm{O}$ under POD and CAT catalysis. The antioxidant enzymes maintain a certain balance with ROS, the product of membrane lipid peroxidation is MDA that can reflect the degree of oxidative stress damage to plants (Jing et al., 2019). Compared with $\mathrm{CK}, \mathrm{O}_{2}{ }^{-}$generation rate, $\mathrm{H}_{2} \mathrm{O}_{2}$ content, MDA content, the activity of SOD, POD and CAT increased significantly under SAS treatment. During saline-alkali stress condition, the root of maize was affected by oxidative stress, the change of 
antioxidant enzyme activity in Jilong2 was greater than that in Xinxuan58. ROS accumulation cause damages to membrane structure and the imbalance between prooxidant and anti-oxidant systems and then following oxidative stress (Liu et al., 2017). Compared with SAS treatment, $\mathrm{O}_{2}^{-}$generation rate, $\mathrm{H}_{2} \mathrm{O}_{2}$ content, MDA content, the activity of SOD, POD and CAT decreased significantly under GD treatment. GD treatment alleviates the oxidative stress damage caused by saline-alkali stress on maize roots, and effectively improves the saline-alkali tolerance of maize, Xinxuan58 is more sensitive to GD effects. The increased activity of antioxidant enzymes can effectively scavenge ROS (Abdelgawad et al., 2016; Yao et al., 2016; Elrys et al., 2020). $25 \mathrm{mg} \mathrm{L}^{-1}$ GD significantly reduced SOD and POD activity in green vegetable leaves (Yan et al., 2016). $1 \mathrm{mg} \mathrm{L}^{-1} \mathrm{GD}$ effectively reduced SOD activity in maize leaves (Qian et al., 2015). In this study the GD treatment could significantly improve the activity of SOD, POD and CAT, which appear to be at odds with that conclusion, due to different GD concentrations on antioxidant oxidase activity.

\section{Conclusions}

In conclusion, this study demonstrated that exogenous GD increased tolerance to saline-alkali stress in maize. Under saline-alkali stress, GD could reduce the harmful effects on the growth of maize by regulating osmotic metabolism, activating photosynthesis, enhancing the antioxidant system and increasing endogenous content. These results revealed a key role of GD in the relief of saline-alkali stress and indicated that it can be used as root-promoting agent. The physiological mechanism of GD on maize seedling growth promotion and saline-alkali stress tolerance is not clear. The next step is to determine the effect of GD on carbon and nitrogen metabolism of maize seedlings to determine the role of GD under saline-alkali stress.

Acknowledgments. The authors would like to acknowledge the contributions and support of Northeast Agricultural University and lab teams, Li Congfeng from the Institute of Chinese Academy of Agricultural Sciences Crop Science, Mingquan Wang, Liguo Zhang and Lin Piao from Heilongjiang the Academy of Agricultural Sciences Maize Institute, and Qianrong Zhu from Guangxi Shan Yun Biochemical Science and Technology Co., Ltd.

Author contributions. Liu, Z., Gu, W. R., Li, J., and Wei, S. conceptualized and planned the study. Liu, Z., Zhu, Q. R., Li, C. F., and Xu, W. H. conducted the experiments and prepared samples. Liu, Z., and Wang, M. Q. conducted the laboratory analyses. Liu, Z. interpreted the results. Liu, Z., and Gu, W. R. wrote the manuscript with contributions from all authors.

Funding information. This research was funded by the National Key R\&D Program of China (2017YFD0300506, 2016YFD0300103), Heilongjiang Provincial Funding for National Key R\&D Programs of China (GX18B029) and "Academic Backbone" Project of Northeast Agricultural University (17XG23).

Conflict of interests. The authors declare that they have no conflicts of interests.

\section{REFERENCES}

[1] Abdelgawad, H., Zinta, G., Hegab, M. M., Pandey, R., Asard, H., Abuelsoud, W. (2016): High salinity induces different oxidative stress and antioxidant responses in maize seedlings organs. - Frontiers in Plant Science 7: 276. 
[2] Ahmad, I., Kamran, M., Meng, X. P., Ali, S., Bilegjargal, B., Cai, T., Liu, T., Han, Q. F. (2019): Effects of plant growth regulators on seed filling, endogenous hormone contents and maize production in semiarid regions. - Journal of Plant Growth Regulation 38(4): $1467-1480$.

[3] Amany, A. R., Ebtiha, M. A. E., Mervat, S. S. (2019): Comparative study for the effect of arginine and sodium nitroprusside on sunflower plants grown under salinity stress conditions. - Bulletin of the National Research Centre 43(1): 1-12.

[4] Amira, F. Y. E., Taha, I. B. (2020): Sustainable cultivation under saline irrigation water: alleviating salinity stress using different management treatments on Terminalia Arjuna (Roxb.) Wight \& Arn. - Agricultural Water Management 229: 105902.

[5] Borba, A. R., Serra, T. S., Gorska, A., Gouveia, P., Cordeiro, A. M., Reyna, L. I., Knerova, J., Barros, P. M. (2018): Synergistic binding of bHLH transcription factors to the promoter of the maize NADP-ME gene used in $\mathrm{C}_{4}$ photosynthesis is based on an ancient code found in the ancestral $\mathrm{C}_{3}$ state. - Molecular Biology and Evolution 35(7): 1690-1705.

[6] Dong, M., Kuerban, Z., Lü, P., Du, R. H., Ye, K., Hou, S. L., Liu, G. Q. (2019): Transcriptome analysis and gene mining of salt tolerance in sorghum seedlings (Sorghum bicolor L. Moench). - Scientia Agricultura Sinica 52(22): 3987-4001. (in Chinese).

[7] Elrys, A. S., Abdo, A. I. E., Abdel-Hamed, E. M. W., Desoky, E. M. (2020): Integrative application of licorice root extract or lipoic acid with fulvic acid improves wheat production and defenses under salt stress conditions. - Ecotoxicology and Environmental Safety 190: 110144.

[8] Huang, S. R., Du, J. B., Wang, X. C., Sun, X., Yang, W. Y. (2019): Involvement of carbohydrates in long-term light-dependent systemic regulation on photosynthesis of maize under light heterogeneity. - Plant Signaling and Behavior 14(8): 1-4.

[9] Hughes, T. E., Sedelnikova, O. V., Wu, H., Becraft, P. W., Langdale, A. J. A. (2019): Redundant SCARECROW genes pattern distinct cell layers in roots and leaves of maize. - Development 146(14): dev177543.

[10] Jan, F. G., Hamayun, M., Hussain, A., Iqubal, A., Jan, G., Khan, S. A., Khan, H., Lee, I. J. (2019): A promising growth promoting Meyerozyma caribbica from Solanum xanthocarpum alleviated stress in maize plants. - Bioscience Reports 39(10): BSR20190290.

[11] Jing, Y. P., Li, Y. J., Lin, Y. L., Li, H. C., Li, X. P., Sha, N., Li, Y. F. (2019): Comprehensive evaluation of physiological response and saline-alkali resistance of maize to $\mathrm{Na}_{2} \mathrm{CO}_{3}$ stress. - China Soils Fertilizer 5: 179-186. (in Chinese).

[12] Joshua, W., Jessica, G. D., Heather, S. (2019): Influence of light on endogenous phytohormone concentrations of a nitrogen-fixing Anabaena sp. cyanobacterium culture in open raceways for use as fertilizer for horticultural crops. - Journal of Applied Phycology 31(6): 3371-3384.

[13] Kandoi, D., Mohanty, S., Tripathy, B. C. (2018): Overexpression of plastidic maize NADP-malate dehydrogenase (ZmNADP-MDH) in Arabidopsis thaliana confers tolerance to salt stress. - Protoplasma 255(2): 547-563.

[14] Kaya, C., Akram, N. A., Ashraf, M., Sonmez, O. (2018): Exogenous application of humic acid mitigates salinity stress in maize (Zea mays L.) plants by improving some key physico-biochemical attributes. - Cereal Research Communications 46(1): 67-78.

[15] Lei, M. Y., Xu, W. G., Li, X. B., Zhang, Q. C., Wang, H. W., Zhang, W., Fang, Y. H., Li, Y., Li, C. X. (2017): Effect of maize $\mathrm{C}_{4}$-specific photosynthesis genes on photosynthesis and drought resistance of Arabidopsis thaliana. - Journal of Triticeae Crops 37(1): 108115. (in Chinese).

[16] Li, X. Y., Yang, Y., Zhang, L. F., Zuo, S. Y., Li, L. J., Jiao, J., Li, J. (2017): Regulation on contents of endogenous hormones and Asr1 gene expression of maize seedling by exogenous ABA under low-temperature stress. - Acta Agronomica Sinica 43(1): 141148. (in Chinese). 
[17] Li, Y. X., Liu, B. Y., Peng, Y. X., Liu, C. L., Zhang, X. Z., Zhang, Z. J., Liang, W., Ma, F. W., Li, C. Y. (2020): Exogenous GABA alleviates alkaline stress in Malus hupehensis by regulating the accumulation of organic acids. - Scientia Horticulturae 261: 108982.

[18] Litalien, I. A., Zeeb, B. (2020): Curing the earth: A review of anthropogenic soil salinization and plant-based strategies for sustainable mitigation. - Science of the Total Environment 698: 134235.

[19] Liu, Y., Li, B., Sun, W. T., Yu, Y. (2017): Effects of bio-organic fertilizer on physiological characters and yield of maize in saline-alkali soil. - Crops 2: 98-103. (in Chinese).

[20] Lu, C. C., Chen, M. X., Liu, R., Zhang, L., Hou, X. X., Liu, S. X., Ding, X. H., Jiang, Y., Xu, J. D., Zhang, J. H., Zhan, X. Y., Liu, Y. G. (2019): Abscisic acid regulates auxin distribution to mediate maize lateral root development under salt stress. - Frontiers in Plant Science 10: 716.

[21] Mukhtar, S., Zareen, M., Khaliq, Z., Mehnaz, S., Malik, K. A. (2019): Phylogenetic analysis of halophyte-associated rhizobacteria and effect of halotolerant and halophilic phosphate-solubilizing biofertilizers on maize growth under salinity stress conditions. Journal of Applied Microbiology 128(2): 556-573.

[22] Qian, S. Q., Long, Q., Cheng, P., Cheng, G., Zhu, J. W. (2015): Effect of geniposide on the growth of maize seedlings. - Jiangsu Journal of Agricultural Sciences 43(2): 108-110. (in Chinese).

[23] Qian, S. Q., Chen, G., Zhu, M., Zhuang, G. C., Zhu, J. W., Zhu, Q. R. (2016): Effect of genipinoside on photosynthetic reaction and biomass of radish. - Jiangsu Journal of Agricultural Sciences 44(3): 171-174. (in Chinese).

[24] Razieh, K., Abdolmajid, R., Jafar, Y., Reza, G. F., Mehdi, Z. (2019): Effect of shrimp waste-derived biochar and arbuscular mycorrhizal fungus on yield, antioxidant enzymes, and chemical composition of corn under salinity stress. - Journal of Soil Science and Plant Nutrition 19(4): 758-770.

[25] Rohman, M. M., Islam, M. R., Monsur, M. B., Amiruzzaman, M., Fujita, M., Hasanuzzaman, M. (2019): Trehalose protects maize plants from salt stress and phosphorus deficiency. - Plants-Basel 8(12): 568.

[26] Sayre, R. T., Kennedy, R. A., Pringnitz, D. J. (1979): Photosynthetic enzyme activities and localization in Mollugo verticillata populations differing in the levels of $\mathrm{C}_{3}$ and $\mathrm{C}_{4}$ cycle operation. - Plant Physiology 64(2): 293-299.

[27] Taha, M. K., Zeinab, M. B., Samar, S. G. (2019): Timing of salicylic acid application affects the response of maize (Zea mays L.) hybrids to salinity stress. - Heliyon 5(4): e01547.

[28] Ueno, Y., Yoshizawa, K. K., Emura, J., Urab, T., Yoshiya, T., Furumoto, T., Izui, K. (2020): In vivo phosphorylation: Development of specific antibodies to detect the phosphorylated PEPC isoform for the $\mathrm{C}_{4}$ photosynthesis in Zea mays. - Methods in Molecular Biology 2072: 217-240.

[29] Wang, M. H., Li, M., Gao, Q., Zhen, S. J., Li, Q., Ggao, H. X., Jin, P. (2016): Effects of amendments on growth and physiological characteristics of maize seedlings on salinealkali soil. - Chinese Journal of Ecology 35(11): 2966-2973. (in Chinese).

[30] Wu, S., Pan, F. M. (2014): SPSS statistical analysis. - Tsinghua University Press, Beijing (in Chinese).

[31] Wu, J., Wang, B., Li, M., Shi, Y. H., Wang, C., Kang, Y. G. (2019): Network pharmacology identification of mechanisms of cerebral ischemia injury amelioration by Baicalin and Geniposide. - European Journal of Pharmacology 859: 172484.

[32] Xie, Q. J., Esseming, J., Pang, X. C., Chen, H. Y., Cai, W. M. (2019): Exogenous application of abscisic acid to shoots promotes primary root cell division and elongation. - Plant Science 292: 110385.

[33] Yan, P., Guo, F. F., Song, X. F., Guan, S. L., Chen, G., Qian, S. Q., Zhu, M., Zhu, J. W., Zhu, Q. R. (2016): Effects of geniposide on photosynthetic reaction and physiological 
indexes of green vegetables. - Jiangsu Journal of Agricultural Sciences 44(4): 193195+526. (in Chinese).

[34] Yao, H. H., Li, Y. S., Zhang, T. Z., Zhao, J., Wang, C., Wang, H. N., Fang, Y. F. (2016): Effects of combined drought and salinity stress on germination and physiological characteristics of maize (Zea mays). - Chinese Journal of Applied Ecology 27(7): 23012307. (in Chinese).

[35] Zhang, B. X., Liu, J. D., Shan, Y. N., Ye, W. W., Diao, Y. P. (1998a): Effect of geniposide on increasing cotton yield. - China Cottage 9: 17. (in Chinese).

[36] Zhang, H. Y., Zhang, B. X., Shan, Y. N., Zhang, J. (1998b): Effect of geniposide and its compound on increasing yield of cucumber and cowpea. - Journal of Changjiang Vegetable 12: 24-26+43. (in Chinese).

[37] Zhang, B. X., Shan, Y. N., Zhang, J., Li, G. X., Ye, X. R. (1999a): Effect of genipinoside and its compound on increasing yield of cowpea. - Shanghai Vegetable 1: 33-34. (in Chinese).

[38] Zhang, B. X., Shang, Y. N., Ye, X. R., Feng, M. Y., Zhang, J. L. (1999b): Effect of geniposide on wheat yield. - Acta Agriculturae Jiangxi 2: 2-6. (in Chinese).

[39] Zhang, Y., Qian, S. Q., Chen, J. (2018): Influence of geniposide on physiological metabolism of willow leaves. - Jiangsu Journal of Agricultural Sciences 46(23): 141-143. (in Chinese).

[40] Zhang, X., Pu, P., Tang, Y., Zhang, L. X., Lv, J. Y. (2019a): C 4 photosynthetic enzymes play a key role in wheat spike bracts primary carbon metabolism response under water deficit. - Plant Physiology and Biochemistry 142: 163-172.

[41] Zhang, X. H., Liu, Y. H., Liu, B. W., Liu, Q., Wen, S. Y., Ao, B., Lin, Z. Q., Zheng, Y. L., Yang, W. Z., Chu, X. T., Xu, Y. F. (2019b): Arbuscular mycorrhiza fungus improved growth, antioxidant defense, and endogenous hormones in tall fescue under low-light stress. - South African Journal of Botany 27: 43-50.

[42] Zhao, J. F., Du, Y. W., Wang, G. H., Li, Y. F., Zhao, F. Y., Wang, Z. H., Cheng, K., Wang, Y. W., Yu, A. L. (2019): Identification NADP-ME gene of foxtail millet and its response to stress. - Scientia Agricultura Sinica 52(22): 3950-3963. (in Chinese).

[43] Zhao, W., Zhou, Q., Tian, Z. Z., Cui, Y. T., Liang, Y., Wang, H. Y. (2020): Apply biochar to ameliorate soda saline-alkali land, improve soil function and increase corn nutrient availability in the Songnen Plain. - Science of the Total Environment 722 : 137428. 